\title{
Faktor yang Mempengaruhi Perilaku Pencegahan Kanker Payudara Pada Mahasiswi Kebidanan STIKes Payung Negeri Tahun 2017
}

\author{
Factors that Influence Behavior The Prevention of Breast Cancer At Student Midwifery STIKes \\ Payung Negeri Pekanbaru In 2017
}

\section{Yoneta Okataviani}

Akademi Kebidanan Husada Gemilang, Tembilahan, Riau email :Yonetayme@yahoo.com

\begin{abstract}
Abstrak
Kanker adalah suatu kondisi dimana sel telah kehilangan pengendalian dan mekanisme normalnya, sehingga mengalami pertumbuhan yang tidak normal, cepat dan tidak terkendali. Kasus kanker payudara di RSUD Arifin Achmad pada tahun 2016 sebanyak 265 Orang. Kasus ini merupakan kasus kanker payudara tertinggi di RSUD Arifin Achmad. Tujuan dari penelitian ini adalah untuk mengetahui faktorfaktor yang mempengaruhi perilaku pencegahan kanker payudara.

Penelitian ini bersifat deskriptif kuantitatif. Penelitian ini dilakukan Pada Program Studi DIII Kebidanan tingkat I dan II STIKes Payung Negeri, pada bulan Juli tahun 2017. Sampel penelitian ini berjumlah 139 mahasiswi yang terdaftar di STIKes Payung Negeri. Desain penelitian yang digunakan adalah Cross Sectional dengan menggunakan instrument penelitian yaitu kuesioner. Data dianalisa secara univariat dan bivariat dengan uji statistic Chi Square.

Hasil penelitian ini menyimpulkan bahwa ada pengaruh pengetahuan ( $p$ value $=0,001<0,05)$ dengan perilaku pencegahan kanker payudara, tidak ada pengaruh sikap ( $p$ value $=0,527>0,05)$ dan riwayat penyakit kanker pada keluarga ( $p$ value $=0,503>0,05$ ) dengan perilaku pencegahan kanker payudara, Serta ada pengaruh usia pertama menarche ( $p$ value $=0,007<0,05)$ dengan perilaku pencegahan kanker payudara.

Hasil penelitian ini direkomendasikan untuk peneliti selanjutnya, untuk menindaklanjuti tentang faktor-faktor yang menyebabkan kanker payudara, sehingga didapatkan hasil yang lebih baik.
\end{abstract}

Kata kunci: Faktor-faktor, perilaku, pencegahan kanker payudara, mahasiswi

\section{Abstract}

Cancer is a condition where cells have lost control and the normal mechanisms, so that experiencing abnormal growth, rapid and uncontrolled. Cases of breast cancer at RSUD Arifin Achmad in 2016 as many 265 people. Case this is a case of breast cancer is highest in the RSUD Arifin Achmad. The purpose of this study was to determine the factors that affect behavior the prevention of breast cancer.
This research is descriptive quantitative. This research conducted was on DIII program studi midwifery level I dan II in STIKes Payung Negeri,in july 2017. This research sampel totaled 139 student registered in the STIKes Payung Negeri. The research design was a cross sectional study using questionnaires instrument. Data were analyzed using univariate and bivariate statistical test Chi Square.

Results of this study concluded that there was influence of knowledge ( $p$ value $=0,001<0,05$ ) with behavior the prevention of breast cancer, there is no influence of attitude ( $p$ value $=0,527>0,05$ ) with behavior the prevention of breast cancer, there is no influence and a history of cancer in the family ( $p$ value $=0,503>0,05$ ) with behavior the prevention of breast cancer, and there was influence the first age of menarche $(p$ value $=0,007<0,05)$ with behavior the prevention of breast cancer.

The results of this study are recommended for further research, for to follow up on the factors that cause breast cancer, so get better results

Keyword: Factors, Attitude, Prevention of breast cancer, Student

\section{Pendahuluan}

Wanita sehat merupakan wanita yang sehat seutuhnya baik tubuh, jiwa dan perilakunya dalam lingkungan dan masyarakat yang sehat. Sehat tidak saja terbebas dari sakit tetapi dalam lingkungan sehat seutuhnya seperti jasmani, rohani dan sosial. Wanita memiliki rambut sebagai mahkota, namun tidak kalah penting bahwa payudara merupakan mahkota yang paling berharga bagi seorang wanita $[1,2,3,4]$.

Kanker adalah suatu kondisi dimana sel telah kehilangan pengendalian dan mekanisme normalnya, sehingga mengalami pertumbuhan yang tidak normal, cepat dan tidak terkendali. Ini adalah jenis kanker paling umum yang 
diderita kaum wanita. Kaum pria juga dapat terserang kanker payudara, walaupun kemungkinannya lebih kecil dari 1 di antara $1000^{[5,6]}$

Kanker payudara disebut juga carcinoma mammae adalah sebuah tumor ganas yang tumbuh dalam jaringan payudara. Tumor ini dapat tumbuh dalam kelenjer susu, jaringan lemak, maupun dalam jaringan ikat payudara [7]. Kanker payudara merupakan suatu jenis kanker yang dapat menyerang siapa saja baik kaum wanita maupun pria. Hingga kini kanker payudara masih menjadi momok terutama pada kaum wanita oleh karena itu kanker payudara ini diidentikkan dengan sebuah keganasan yang dapat berakibat pada kematian $[8,9]$. Pengetahuan perempuan tentang risiko dan manfaat dari deteksi dini kanker payudara berpengaruh positif terhadap keyakinan mereka tentang kesehatan, sikap, dan perilaku, sehingga perawatan kesehatan professional dapat mengembangkan program kesehatan payudara yang efektif $[10,11,12]$.

Saat ini penyakit kanker menjadi masalah kesehatan utama baik di dunia maupun di Indonesia. Menurut data WHO tahun 2013, insiden kanker meningkat dari 12,7 juta kasus tahun 2008 menjadi 14,1 juta kasus tahun 2012. Sedangkan jumlah kematian meningkat dari 7,6 juta orang tahun 2008 menjadi 8,2 juta pada tahun 2012. Kanker menjadi penyebab kematian nomor 2 di dunia sebesar $13 \%$ setelah penyakit kardiovaskular. Diperkirakan pada 2030 insiden kanker dapat mencapai 26 juta orang dan 17 juta di antaranya meninggal akibat kanker, terlebih untuk negara miskin dan berkembang kejadiannya akan lebih cepat $[13,14]$.

Kanker payudara merupakan kanker yang paling banyak menyerang perempuan dan penyebab kematian kedua setelah kanker leher rahim. Diperkirakan jumlah kasus baru tidak kurang dari 1.050.346 per tahun. Dari jumlah itu, 580.000 kasus terjadi di negara maju, sisanya di negara berkembang. Menurut International Union Against Cancer (UICC), sebuah lembaga nonpemerintah internasional yang bergerak di bidang pencegahan kanker, kanker telah membunuh orang lebih banyak daripada total kematian yang diakibatkan AIDS, tuberculosis, dan malaria. Jumlah kematian akan meningkat secara dramatis dalam dekade mendatang jika kita tidak melakukan upaya nyata ${ }^{[15,16]}$

Berdasarkan data Sistem Informasi Rumah Sakit (SIRS) Kementrian Kesehatan pada tahun 2010, kanker payudara menempati urutan pertama jumlah pasien rawat inap kanker di seluruh RS di Indonesia (21,69\%), disusul kanker leher Rahim (17\%). Kanker tertinggi yang diderita wanita Indonesia adalah kanker payudara dengan angka kejadian 26 per 100.000 perempuan, disusul kanker leher rahim dengan 16 per 100.000 perempuan. The American cancer society (2010) kurang lebih 40.910 kasus kematian kanker payudara terdeteksi. Berdasarkan data Rumah sakit kanker Dharmais, Kanker payudara termasuk pada 10 Besar Kanker Tersering Rumah Sakit Kanker Dharmis Rawat Jalan (Kasus Baru) tahun 2008, dengan jumlah sebanyak 657 kasus $[15,17,18,19]$.

Di Indonesia, prevalensi penyakit kanker juga cukup tinggi. Berdasarkan data Riset Kesehatan Dasar (Riskesdas) tahun 2013, prevalensi tumor/kanker di Indonesia adalah 1,4 per 1000 penduduk, atau sekitar 330.000 orang. Kanker tertinggi di Indonesia pada perempuan adalah kanker payudara dan kanker leher rahim. Sedangkan pada laki-laki adalah kanker paru dan kanker kolorektal. Berdasarkan estimasi Globocan, International Agency for Research on Cancer (IARC) tahun 2012, insidens kanker payudara sebesar 40 per 100.000 perempuan, kanker leher rahim 17 per 100.000 perempuan, kanker paru 26 per 100.000 laki-laki kankerkolorektal 16 per 100.000 laki-laki. Berdasarkan data Sistem Informasi Rumah Sakit 2010, kasus rawat inap kanker payudara 12.014 kasus $(28,7 \%)$, kanker leher rahim 5.349 kasus $(12,8 \%)$. 
Berdasarkan data yang diperoleh dari Rumah Sakit Umum Daerah Arifin Achmad Pekanbaru Provinsi Riau, diketahui adanya peningkatan jumlah penderita kanker payudara dari tahun 2014 ada 155 orang, tahun 2015 ada 186 orang dan tahun 2016 ada 265 orang. Pada tahun 2016 memiliki peringkat penemuan kasus kanker payudara yang tertinggi dari pada tahun 2014 dan tahun 2015. Pada usia 25-44 tahun, tahun 2014 dan tahun 2016 penderita kanker payudara adalah kasus tertinggi. Penelitian ini dilakukan pada mahasiswi Program Studi DIII kebidanan tingkat I dan II STIKes Payung Negeri, karena pada tingkat III mereka sedang sibuk dan STIKes Payung Negeri juga merupakan salah satu STIKes yang memiliki jumlah mahasiswi kebidanan yang cukup banyak.

Berdasarkan hasil penelitian di Iraq, terdapat $90,09 \%$ orang pernah mendengar tentang sadari dengan sumber informasi yang utama adalah televisi, namun hanya terdapat $48,3 \%$ yang mempraktikan sadari dengan alasan kurangnya pengetahuan tentang bagaimana melakukan teknik sadari yang benar [20]. Cara melakukan sadari merujuk pada perilaku seseorang dalam pemeliharaa kesehatan payudara, pembentukkan perilaku ini bisa juga melalui pengertian (Insight) dimana menurut Kohler pembentukan perilaku akibat pengertian (Insight) yang diterimanya melalui belajar ${ }^{[21,22,23]}$

Berdasarkan latar belakang, maka peneliti tertarik untuk melakukan penelitian ini guna mengetahui faktor-faktor yang mempengaruhi perilaku pencegahan kanker payudara pada mahasiswi Program Studi DIII kebidanan tingkat I dan II STIKes Payung Negeri Pekanbaru tahun 2017.

\section{Metode Penelitian}

Jenis penelitian ini adalah penelitian deskriptif kuantitatif dengan desain cross sectional, yaitu untuk mengetahui pengaruh antara variabel independen dengan variabel dependen dimana pengumpulan data dilakukan secara sekaligus pada waktu bersamaan.

Populasi dalam penelitian ini adalah seluruh mahasiswi Program studi DIII kebidanan tingkat I dan II yang berada di STIKes Payung Negeri Pekanbaru dengan jumlah 217 orang.

Sampel yang digunakan pada penelitian ini berjumlah $139 \quad$ responden.Untuk mengantisipasi terjadinya dropout atau responden kurang dari 139 orang, peneliti menambahkan $5 \%$ responden cadangan sehingga menjadi 146 responden. Teknik pengambilan sampel secara Sampel Random Berstrata (Stratified Random Sampling) Populasi dibagi strata-strata (sub populasi), kemudian pengambilan sampel dilakukan dalam setiap strata secara acak di setiap kelas yaitu nomor responden saat di acak dari setiap kelas itulah yang menjadi responden Dalam penelitian ini setiap anggota tingkat I dan tingkat II mempunyai kesempatan yang sama untuk diseleksi menjadi sampel.Instrumen dalam penelitian ini adalah angket atau kuesioner yang berupa sejumlah pertanyaan tertulis dengan pertanyaan yang berhubungan dengan masalah yang akan diteliti.

Analisis data dalam penelitian ini menggunakan analisis data Univariat dan analisi data Bivariat.Analisis univariat yaitu menganalisis variabel-variabel karakteristik individu yang ada secara deskriptif dengan menghitung distribusi frekuensi dan proporsinya untuk mengetahui karakteristik dari subyek penelitian.Analisis Bivariat yang dilakukan terhadap dua variabel yang diduga berhubungan dan bertujuan menguji hipotesa antara variabel independen dan dependen.

Untuk mengetahui adanya pengaruh kedua variabel tersebut dilakukan dengan uji ChiSquare dengan derajat kepercayaan $95 \% \mathrm{p}=$ 0.05 . Apabila $p$ value $<0.05$ maka Ho ditolak, artinya menunjukkan pengaruh yang signifikan antara dua variabel.

Berdasarkan hasil penelitian yang telah dilakukan pada tanggal 10-13 Juni 2017 mengenai Faktor - Faktor Yang Mempengaruhi 
Perilaku Pencegahan Kanker Payudara Pada Mahasiswi Program Studi DIII Kebidanan Tingkat I Dan II Stikes Payung Negeri Pekanbaru Tahun 2017, di peroleh hasil analisis univariat dan analisis bivariat dengan jumlah responden 139 orang.

\section{A. AnalisisUnivariat}

\section{Tingkat Pengetahuan Responden}

Tabel 4.1. Distribusi Berdasarkan Tingkat Pengetahuan Responden Mahasiswi Kebidanan STIKes PayungNegeri Pekanbaru

\begin{tabular}{cccc}
\hline No & $\begin{array}{c}\text { Tingkat } \\
\text { Pengetahuan }\end{array}$ & Frekuensi & $\begin{array}{c}\text { Persentase } \\
(\%)\end{array}$ \\
\hline 1 & Rendah & 16 & 11,5 \\
2 & Tinggi & 123 & 88,5 \\
\hline & Jumlah & 139 & 100 \\
\hline
\end{tabular}

(sumber: Data Primer Penelitian 2017)

Berdasarkan tabel 4.1 di dapatkan bahwa dari 139 responden yang memiliki tingkat pengetahuan rendah sebanyak 16 orang (11,5\%) lebih sedikit dibandingkan dengan tingkat pengetahuan tinggi yaitu sebanyak 123 orang $(88,5 \%)$.

\section{Sikap Responden}

Tabel 4.2. Distribusi Berdasarkan Sikap Responden Pada Mahasiswi Mahasiswi Kebidanan STIKes Payung Negeri Pekanbaru

\begin{tabular}{cccc}
\hline $\begin{array}{c}\mathrm{N} \\
\mathrm{O}\end{array}$ & Sikap & Frekuensi & $\begin{array}{c}\text { Persentase } \\
(\%)\end{array}$ \\
\hline 1 & Negatif & 32 & 23,0 \\
2 & Positif & 107 & 77,0 \\
\hline & Jumlah & 139 & 100 \\
\hline
\end{tabular}

(Sumber: Data Primer Penelitian 2017)

Berdasarkan tabel 4.2 di dapatkan bahwa dari 139 responden yang memiliki sikap negatif sebanyak 32 orang $(23,0 \%)$ lebih sedikit di bandingkan dengan sikap positif yaitu sebanyak 107 orang $(77,0 \%)$.

\section{Riwayat Penyakit Kanker Pada Keluarga Responden}

Tabel 4.3. Distribusi Berdasarkan Riwayat Penyakit Kanker Pada Keluarga Responden Pada Mahasiswi Kebidanan STIKes PayungNegeri Pekanbaru

\begin{tabular}{cccc}
\hline No & $\begin{array}{c}\text { Riwayat } \\
\text { Penyakit Kanker } \\
\text { Pada Keluarga }\end{array}$ & $\begin{array}{c}\text { Frekuen } \\
\text { si }\end{array}$ & $\begin{array}{c}\text { Persenta } \\
\text { se (\%) }\end{array}$ \\
\hline 1 & Ya & 14 & 10,1 \\
2 & Tidak & 125 & 89,9 \\
\hline & Jumlah & 139 & 100 \\
\hline
\end{tabular}

(Sumber: Data Primer Penelitian 2017)

Berdasarkan tabel 4.3 di dapatkan bahwa dari 139 responden yang memiliki riwayat penyakit kanker Pada keluarga sebanyak 14 orang $(10,1 \%)$ lebih sedikit dibandingkan dengan yang tidak memiliki riwayat penyakit kanker Pada keluarga yaitu sebanyak 125 orang $(89,9 \%)$.

\section{Usia Pertama Menarche Responden}

Tabel 4.4. Distribusi Berdasarkan UsiaPertama Menarche Responden Pada Mahasiswi Kebidanan STIKes Payung Negeri Pekanbaru

\begin{tabular}{cccc}
\hline No & $\begin{array}{c}\text { Usia } \\
\text { Pertama } \\
\text { Menarche }\end{array}$ & Frekuensi & $\begin{array}{c}\text { Persentase } \\
(\%)\end{array}$ \\
\hline 1 & $<12$ tahun & 44 & 31,7 \\
2 & $\geq 12$ tahun & 95 & 68,3 \\
\hline & Jumlah & 139 & 100 \\
\hline
\end{tabular}

(sumber: Data Primer Penelitian 2017

Berdasarkan tabel 4.4 di dapatkan bahwa dari 139 responden yang usia pertama menarche $<12$ tahun sebanyak 44 orang $(31,7 \%)$ lebih sedikit dibandingkan dengan usia pertama menarche $\geq 12$ tahun yaitu sebanyak 95 orang $(68,3 \%)$. 


\section{Perilaku Pencegahan}

Tabel 4.5. Distribusi Berdasarkan Perilaku Pencegahan Responden Pada Mahasiswi Kebidanan STIKes Payung Negeri Pekanbaru Tahun 2017

\begin{tabular}{|c|c|c|c|}
\hline No & Sikap & Frekuensi & $\begin{array}{c}\text { Persentase } \\
(\%)\end{array}$ \\
\hline 1 & $\begin{array}{l}\text { Tidak } \\
\text { mencegah }\end{array}$ & 35 & 25.2 \\
\hline 2 & Mencegah & 104 & 74,8 \\
\hline & Jumlah & 139 & 100 \\
\hline
\end{tabular}

Berdasarkan tabel 4.5 di dapatkan bahwa dari 139 responden yang tidak mencegah sebanyak 35 orang $(25,0 \%)$ lebih sedikit di bandingkan dengan yang mencegah yaitu sebanyak 104 orang $(74,8 \%)$.

\section{B. Analisis Bivariat}

1. Pengaruh Tingkat Pengetahuan Dengan Perilaku Pencegahan Kanker Payudara

Tabel 4.6. Analisis Pengaruh Tingkat Pengetahuan Dengan Perilaku Pencegahan Kanker Payudara Pada Mahasiswi Kebidanan STIKes PayungNegeri Pekanbaru

\begin{tabular}{|c|c|c|c|c|c|c|c|c|}
\hline \multirow[t]{3}{*}{$\mathbf{P}$} & \multicolumn{4}{|c|}{ Perilaku Pencegahan Kanker Payudara } & \multirow{2}{*}{\multicolumn{2}{|c|}{ Total }} & \multirow{3}{*}{$\begin{array}{c}\mathbf{P} \\
\text { Value }\end{array}$} & \multirow{2}{*}{$\begin{array}{c}\text { POR } \\
95 \% \mathrm{CI}\end{array}$} \\
\hline & \multicolumn{2}{|c|}{ Tidak mencegah } & \multicolumn{2}{|c|}{ Mencegah } & & & & \\
\hline & $\sum$ & $\%$ & $\sum$ & $\%$ & $\sum$ & $\%$ & & \\
\hline Rendah & 10 & 62,5 & 6 & 37,5 & 16 & 100 & 0,001 & 3,176 \\
\hline Tinggi & 25 & 20,3 & 98 & 79,7 & 123 & 100 & & $1,43-7,05$ \\
\hline Total & 35 & 25,2 & 104 & 74,8 & 139 & 100 & & \\
\hline
\end{tabular}

(Sumber: Data Primer Penelitian 2017)

Berdasarkan tabel 4.6 di dapatkan bahwa sebanyak 16 responden yang memiliki tingkat pengetahuannya rendah sebanyak 10 responden $(62,5 \%)$ diantaranya tidak melakukan pencegahan kanker payudara, sedangkan sebanyak 6 responden $(37,5 \%)$ melakukan pencegahan kanker payudara. Sementara sebanyak 123 responden yang memiliki tingkat pengetahuannya tinggi sebanyak 25 responden $(20,3 \%)$ sedangkan yang melakukan pencegahan kanker payudara sebanyak 98 orang $(79,7 \%)$.Hasil uji statistik diperoleh nilai $\mathrm{P}$ value sebesar $0,001<0,05$ sehingga dapat dinyatakan bahwa terdapat pengaruh yang signifikan antara pengetahuan mahasiswi dengan perilaku pencegahan kanker payudara, maka Ho ditolak.

Dari hasil analisis diperoleh juga nilai $O d d s$ Ratio (OR) sebesar 6,533, artinya mahasiswi yang berpengetahuan tinggi memiliki peluang 7 kali untuk berperilaku pencegahan kanker payudara dibandingkan mahasiswi berpengetahuan rendah.Hal ini berarti terdapat pengaruh antara pengetahuan terhadap pencegahan kanker payudara. 


\section{Pengaruh Sikap Dengan Perilaku Pencegahan Kanker Payudara}

Tabel 4.7. Analisis Pengaruh Sikap DenganPerilaku PencegahanKanker Payudara Pada Mahasiswi Kebidanan STIKes PayungNegeri Pekanbaru

\begin{tabular}{|c|c|c|c|c|c|c|c|c|}
\hline \multirow[t]{3}{*}{ Sikap } & \multicolumn{4}{|c|}{ Perilaku Pencegahan Kanker Payudara } & \multirow{2}{*}{\multicolumn{2}{|c|}{ Total }} & \multirow{2}{*}{$\begin{array}{c}\mathbf{P} \\
\text { Value }\end{array}$} & \multirow{2}{*}{$\begin{array}{c}\text { POR } \\
95 \% \mathrm{CI}\end{array}$} \\
\hline & \multicolumn{2}{|c|}{ Tidak mencegah } & \multicolumn{2}{|c|}{ Mencegah } & & & & \\
\hline & $\sum$ & $\%$ & $\sum$ & $\%$ & $\sum$ & $\%$ & & \\
\hline Negatif & 10 & 31,1 & 22 & 68,8 & 32 & 100 & 0,503 & $1,4910,62-3,56$ \\
\hline Positif & 25 & 23,4 & 82 & 76,6 & 107 & 100 & & \\
\hline Total & 35 & 25,2 & 104 & 74,8 & 139 & 100 & & \\
\hline
\end{tabular}

(Sumber: Data Primer Penelitian 2017)

Berdasarkan tabel 4.7 di dapatkan bahwa sebanyak 32 responden yang memiliki sikap negatif sebanyak 10 responden $(31,1 \%)$ diantaranya tidak melakukan pencegahan kanker payudara, sedangkan sebanyak 22 responden $(68,8 \%)$ melakukan pencegahan kanker payudara. Sementara sebanyak 107 responden yang memiliki sikap positif sebanyak 25 responden $(23,4 \%)$, sedangkan yang melakukan pencegahan kanker payudara sebanyak 82 orang $(76,6 \%)$.

Hasil uji statistik diperoleh nilai $\mathrm{P}$ value sebesar $0,503>0,05$ sehingga dapat dinyatakan bahwa tidak terdapat pengaruh yang signifikan antara sikap mahasiswi dengan perilaku pencegahan kanker payudara. Hal ini berarti tidak terdapat pengaruh antara sikap terhadap pencegahan kanker payudara

\section{Pengaruh Riwayat Penyakit Kanker Pada Keluarga Dengan Perilaku Pencegahan Kanker Payudara}

Tabel 4.8. Analisis Pengaruh Riwayat Penyakit Kanker Pada Keluarga Dengan Perilaku Pencegahan Kanker Payudara Pada Mahasiswi Kebidanan STIKes PayungNegeri Pekanbaru

\begin{tabular}{|c|c|c|c|c|c|c|c|c|}
\hline \multirow[t]{3}{*}{ Riwayat PKK } & \multicolumn{4}{|c|}{ Perilaku Pencegahan Kanker Payudara } & \multicolumn{2}{|c|}{ Total } & \multirow{2}{*}{$\begin{array}{c}\mathbf{P} \\
\text { Value }\end{array}$} & \multirow{2}{*}{$\begin{array}{c}\text { POR } \\
95 \% \mathrm{CI}\end{array}$} \\
\hline & \multicolumn{2}{|c|}{ Tidak mencegah } & \multicolumn{2}{|c|}{ Mencegah } & & & & \\
\hline & $\sum$ & $\%$ & $\sum$ & $\%$ & $\sum$ & $\%$ & & \\
\hline Ya & 5 & 35.7 & 9 & 64,3 & 14 & 100 & 0,527 & 1,759 \\
\hline Tidak & 30 & 24,0 & 95 & 76,0 & 125 & 100 & & $0,547-5,655$ \\
\hline Total & 35 & 25,2 & 104 & 74,8 & 139 & 100 & & \\
\hline
\end{tabular}

(Sumber: Data Primer Penelitian 2017)

Berdasarkan tabel 4.8 di dapatkan bahwa sebanyak 14 responden yang menyatakan mempunyai riwayat penyakit kanker pada keluarga sebanyak 5 responden $(35,7 \%)$ diantaranya yang melakukan pencegahan kanker payudara, sedangkan sebanyak 9 responden $(64,3 \%)$ melakukan pencegahan kanker payudara. Sementara sebanyak 125 responden yangmenyatakan mempunyai riwayat penyakit kanker pada keluarga sebanyak 30 responden $(24,0 \%)$ sedangkan yang melakukan pencegahan kanker payudara sebanyak 95 orang $(76,0 \%)$.

Hasil uji statistik diperoleh nilai $\mathrm{P}$ value sebesar $0,527>0,05$ sehingga dapat dinyatakan bahwa tidak terdapat pengaruh yang signifikan antara riwayat penyakit kanker payudara mahasiswi dengan perilaku pencegahan kanker payudara, maka Ho gagal ditolak. Hal ini berarti tidak terdapat pengaruh antara riwayat penyakit kanker pada keluarga terhadap pencegahan kanker payudara. 


\section{Pengaruh Usia Pertama Menarche Dengan Perilaku Pencegahan Kanker Payudara}

Tabel 4.9. Analisis Pengaruh Usia Pertama Menarche Dengan Perilaku Pencegahan Kanker Payudara Pada Mahasiswi Kebidanan STIKes PayungNegeri Pekanbaru

\begin{tabular}{|c|c|c|c|c|c|c|c|}
\hline \multirow[t]{2}{*}{ Usia PM } & \multicolumn{3}{|c|}{ Perilaku Pencegahan Kanker Payudara } & \multicolumn{2}{|c|}{ Total } & \multirow{2}{*}{$\begin{array}{c}\mathbf{P} \\
\text { Value }\end{array}$} & \multirow{2}{*}{$\begin{array}{l}\text { POR } \\
95 \% \mathrm{CI}\end{array}$} \\
\hline & $\begin{array}{c}\text { Tidak } \\
\text { mencegah }\end{array}$ & & & & & & \\
\hline & $\sum \%$ & $\sum$ & $\%$ & $\sum$ & $\%$ & & \\
\hline$<12^{\text {th }}$ & $18 \quad 40,9$ & 26 & 59,1 & 44 & 100 & 0,007 & 3,176 \\
\hline$\geq 12^{\text {th }}$ & 17,9 & 78 & 82,1 & 95 & 100 & & $\begin{array}{l}1,43- \\
7,05\end{array}$ \\
\hline Total & 25,2 & 104 & 74,8 & 139 & 100 & & \\
\hline
\end{tabular}

Berdasarkan tabel 4.9 di dapatkan bahwa sebanyak 44 responden yang menyatakan usia pertama menarche $<12$ tahun sebanyak 18 responden $(40,9 \%)$ diantaranya tidak melakukan pencegahan kanker payudara, sedangkan sebanyak 26 responden $(59,1 \%)$ melakukan pencegahan kanker payudara. Sementara sebanyak 95 responden yang menyatakan usia pertama menarche $<12$ tahun sebanyak 17 responden $(17,9 \%)$ sedangkan yang melakukan pencegahan kanker payudara sebanyak 78 orang $(74,8 \%)$. Hasil uji statistik diperoleh nilai $\mathrm{P}$ value sebesar $0,007<0,05$ sehingga dapat dinyatakan bahwa terdapat pengaruh yang signifikan antara usia pertama menarche mahasiswi dengan perilaku pencegahan kanker payudara, maka $\mathrm{H} 0$ ditolak.

Dari hasil analisis diperoleh juga nilai $O d d s$ Ratio (OR) sebesar 3,176, artinya mahasiswi yang usia pertama menarche $\geq 12$ tahun memiliki peluang 3 kali untuk berperilaku pencegahan kanker payudara dibandingkan mahasiswi

\section{Pembahasan}

Terdapat pengaruh yang signifikan antara tingkat pengetahuan mahasiswi dengan perilaku pencegahan kanker payudara di STIKes Payung Negeri Pekanbaru. Mahasiswi yang tingkat pengetahuan tinggi memiliki peluang 7 kali untuk berperilaku pencegahan kanker payudara dibandingkan mahasiswi berpengetahuan rendah.

Hal ini sesuai dengan teori Bloom, bahwa pengetahuan kognitif merupakan domain yang sangat penting dalam membentuk tindakan seseorang, sehinggauntuk mahasiswi kebidanan agar lebih meningkatkan pengetahuan dengancara aktif mengikuti penyuluhan-penyuluhan, banyak membaca dan mencari informasi tentang kanker payudara dari media cetak maupun media elektronik dalam menerapkan perilaku pencegahan kanker payudara. [10,18]

Menurut penelitian Putri (2014) menunjukan hasil yang sama yaitu sama sig atau $\mathrm{p}$ value $0.002<0.05$ sehingga disimpulkan bahwa ada pengaruh yang signifikan antara pengetahuan responden tentang kanker payudara dengan perilaku pencegahan kanker payudara. ${ }^{[1,3]}$

Peneliti menyimpulkan bahwa pengetahuan seseorang akan berpengaruh terhadap perilaku, jika pengetahuan seseorang tinggi maka perilaku seseorang tersebut cenderung kearah yang baik tapi jika pengetahuan rendah maka perilaku cenderung kearah yang tidak baik. Sehingga hendaknya mahasiswi mencari imformasi mengenai perilaku pencegahan kanker payudara lebih ditingkatkan dengan cara seperti penyuluhan, pelatihan, seminar, pamaren dan kegiatan kesehatan lainya.

Sebanyak $(77,0 \%)$ mahasiswi yang memiliki sikap positif melakukan perilaku pencegahan kanker payudara sehingga dengan 
perilaku pencegahan yang benar, mahasiswi tidak lagi melakukan sikap yang salah melalui sumber yang dapat menimbulkan kesalahpahaman atau emosi negatif.

Menurut Notoatmodjo, sikap merupakan reaksi atau respon seseorang yang masih tertutup terhadap suatu stimulus atau objek. Sikap tidaksama dengan perilaku dan perilaku tidak selalu mencerminkam sikap seseorang sebab sering kali terjadi bahwa seseorang memperlihatkan tindakan yang bertentangan dengan sikapnya. ${ }^{[18,20]}$

Berdasarkan hasil uji statistik diperoleh nilai $\mathrm{P}$ value sebesar $0,503>0,05$, hal ini berarti tidak terdapat pengaruh yang signifikan antara sikap responden dengan perilaku pencegahan kanker payudara di STIKes Payung Negeri Pekanbaru. Sehinggasikap mahasiswi tidak dapat dikaitkan dengan perilaku pencegahan kanker payudara

Menurut penelitian Putri menunjukan hasil yang sama yaitu sama sig atau $\mathrm{p}$ value $0.395<0,05$ sehingga disimpulkan bahwa tidak ada pengaruh yang signifikan antara sikap responden tentang kanker payudara dengan perilaku pencegahan kanker payudara ${ }^{[1,12]}$

Peneliti menyimpulkan bahwa seseorang akan bersikap positif apabila besarnya stimulus positif yang diterima seseorang dan seseorang akan bersikap negatif apabila stimulus yang diterimanya sedikit.

Berdasarkan hasil penelitian sebanyak $(89,9 \%)$ mahasiswi yang mempunyai riwayat penyakit kanker pada keluarga melakukan perilaku pencegahan kanker payudara. Jika ibu dan saudara wanitanya menderita kanker payudara maka kemungkinan seorang tersebut akan memilikili resiko kanker payudara 2 kali dibandingkan wanita lain yang dalam keluarganya tidak ada penderita satupun ${ }^{[11,21,23]}$

Berdasarkan hasil uji statistik diperoleh nilai $\mathrm{P}$ value sebesar $0,527>0,05$, hal ini berarti tidak terdapat pengaruh yang signifikan antara riwayat penyakit kanker pada keluarga dengan perilaku pencegahan kanker payudara di STIKes Payung Negeri Pekanbaru. Sehingga riwayat penyakit kanker pada keluarga mahasiswi tidak dapat dikaitkan dengan perilaku pencegahan kanker payudara

Peneliti menyimpulkan bahwa mahasiswi kebidanan STIKes Payung Negeri lebih banyak yang tidak memiliki riwayat penyakit kanker pada keluarga. Sebaiknya mahasiswi hendaknya mencari sumber imformasi mengenai perilaku pencegahan kanker payudara lebih ditingkatkan dengan cara seperti penyuluhan, pelatihan, seminar, pamaren dan kegiatan kesehatan lainya, bertujuan untuk mencegah resiko terkena kanker payudara baik dalam faktor riwayat penyakit pada kanker keluarga maupun faktor resiko lainnya.

Mahasiswi yang usia pertama menarche $\geq$ 12 tahun memiliki peluang 3 kali untuk berperilaku pencegahan kanker payudara dibandingkan mahasiswi yang usia pertama menarche $<12$ tahun.

Hal ini sesuai dengan teori fitria Resiko menderita kanker payudara adalah 2-4 kali lebih besar pada wanita yang mengalami menarche sebelum usia 12 tahun.Hal ini Semakin dini menarche, semakin besar pulak resiko menderita kanker payudara pada usia $<$ 12 tahun. $^{[4,19,20]}$

Hasil didapatkan nilai $\mathrm{p}=0,003<0.05$, dengan demikian hipotesis nol (Ho) ditolak dan hipotesis alternatif (Ha) diterima. Berarti pada tingkat kemaknaan $5 \%$ terdapat hubungan yang bermakna antara usia menarche dengan kejadian kanker payudara.

Peneliti menyimpulkan bahwa mahasiswi yang usia menarche nya $<12$ tahun mempunyai peluang mendapatkan kanker payudara lebih besar daripada mahasiswi yang usia menarche nya $\geq 12$ tahun.sehingga semakin dini seseorang mengalami menarche semakin besar resiko menderita kanker payudara. 


\section{Kesimpulan}

Berdasarkan hasil penelitian, dapat disimpulkan bahwa faktor - faktor yang mempengaruhi dengan perilaku pencegahan kanker payudara pada mahasiswi Program Studi DIII kebidanan tingkat I dan II STIKes Payung Negeri Pekanbaru tahun 2017 sebagai berikut :

1. Terdapat pengaruh yang signifikan antara tingkat pengetahuan dengan perilaku pencegahan kanker payudara pada mahasiswi Program Studi DIII kebidanan tingkat I dan II STIKes Payung Negeri Pekanbaru tahun 2017 dengan nilai P value sebesar $0,001<0,05$.

2. Tidak terdapat pengaruh yang signifikan antara sikap dengan perilaku pencegahan kanker payudara pada mahasiswi Program Studi DIII kebidanan tingkat I dan II STIKes Payung Negeri Pekanbaru tahun 2017 dengan nilai $\mathrm{P}$ value sebesar 0,503 > 0,05 .

3. Tidak terdapat pengaruh yang signifikan antara riwayat penyakit kanker pada keluarga dengan perilaku pencegahan kanker payudara pada mahasiswi Program Studi DIII kebidanan tingkat I dan II STIKes Payung Negeri Pekanbaru tahun 2017 dengan nilai $\mathrm{P}$ value sebesar 0,527> 0,05 .

\section{Saran}

1. Bagi Peneliti

Mengerahkan peneliti untuk melatih kemampuan analisis penelitian yang lebih baik khususnya mengenai perilaku pencegahankanker payudara.

2. Bagi Mahasiswi STIKes Payung Negeri Pekanbaru

Untuk mahasiswi perlu mengikuti pendidikan kesehatan mengenai perilaku pencegahan kanker payudara sehingga dapat meningkatkan pengetahuan mahasiswi khususnya mengenai perilaku pencegahan kanker payudara yang tepat dan benar.

3. Bagi Peneliti Selanjutnya

Untuk peneliti selanjutnya dapat menggunakannya sebagai bahan acuan serta sebagai dasar untuk pengembangan dalam penelitian selanjutnya, sehinngga didapatkan hasil yang lebih baik.

\section{Daftar Pustaka}

1. Aneldawati Syah Putri. 2014. Analisa Perilaku Wanita Usia Diatas 45 Tahun Terhadap Pencegahan Kanker Payudara Di RT 02 RW 01 Kelurahan Sidomulyo Barat Kecamatan Tampan Kota Pekanbaru Tahun 2014. Pekanbaru : STIKes Hang Tuah

2. Arikunto, S. 2013. Prosedur Penelitian Suatu Pendekatan Praktik. Jakarta :Rineka Cipta

3. Astuti, 2006. Hubungan Pengetahuan dan Sikap Remaja Putri Terhadap Kanker Payudara dengan Minat Melakukan Periksa Payudara Sendiri di SMP Negeri 2 Medan, diakses tanggal 28 Mei 2015.

4. Fitria Meiriza Syahasti. 2016. Faktorfaktor yang berhubungan dengan kejadian kanker payudara pada usia 25-65 tahun di poliklinik onkologi rumah sakit umum daerah arifin achmad tahun 2016. Pekanbaru : STIKes Hang Tuah

5. Ghazali, 2007.Carcinoma Mamae Pada Wanita, diakses tanggal 28 mei 2015.

6. Setiati, E. 2009 Waspada 4 Kanker Ganas Pembunuh Wanita. Yogyakarta: AND

7. Suryaningsih, 2009. Kupas Tuntas Kanker Payudara. Yogyakarta : Paragdima Indonesia

8. Soemitro, P.M. 2012. Blak-blakan kanker payudara.Bandung : Mizan Pustaka

9. Nugroho, S.H.S. 2009. Terapi Pengobatan Tumor-Kanker. Yogyakarta: Kanisius

10. Erbil.,\& Bolukbas. 2012. Beliefs, attitudes, and behavior of Turkish women about breast cancer and breast self- 
examination according to a Turkish version of the Champion Health Belief Model Scale. AsianPacific Journal Cancer Prevention

11. Atmaningtyas, M, N. 2009. Cantik Dan Sehat Payudara. Jakarta : Getar Hati

12. Notoatmojo. 2016. Promosi Kesehatan Dan Ilmu Perilaku . Jakarta: Rineka Cipta

13. Depkes, RI. 2013. diakses melalui (http://www.depkes.go.id/article/print/201 407070001/hilangkan-mitos-tentangkanker.htmlwebsite www.depkes.go.id, diakses 14 Juni 2017)

14. Medical Record RSUD Arifin Ahcmad Provinsi Riau, (2015). Data Penderita Kanker Payudara. Pekanbaru : RSUD Arifin Ahmad Provinsi Riau.

15. Rasjidi, Iman. 2009.Deteksi Dini Dan Pencegahan Kanker Pada Wanita. Jakarta: Agung Seto

16. Joe, W. 2012. Makanan Pembunuh Kanker. Yogyakarta: ANDI

17. Bustan, M.N. 2007. Epedemiologi Penyakit Tidak Menular. Jakarta: Rineka Cipta

18. Notoadmodjo, Soekidjo. 2010. Ilmu Perilaku Kesehatan. Jakarta: Rineka Cipta

19. 2010. Epidemiologi Kanker Pada Wanita. Jakarta: Agung Seto

20. Widjadja, R, 2009. Penyakit Kronis Tindakan, Pencegahan, Pengobatan Secara Medis Maupun Tradisional. Jakarta : bee media Indonesia (UICC Committee On Clinical Stage Classification And Applied Statistic. Clinical Stage Classification And Presentation Of Results, Malignant Tumors Of The Breast And Larynk. Paris: International Union Against Cancer: 1958)

21. Miller, Greg. 2008. Pencegahan Dan Pengobatan Penyakit Kanker. Jakarta : Pustakaraya

22. Amelia, Lena. 2009. Mengobati Kanker Serviks Dan 32 Jenis Kanker Lainnya. Yogyakarta: Perum Jambusari Indah
23. Aryatiningsih, Dwi Sapta. 2012. Health Care Jurnal Kesehatan. 3(1),33-36 